Journal of Business Management and
Economic Research

\title{
THE EFFECT OF WORK LOADS ON EMPLOYEE PERFORMANCE WITH JOB SATISFACTION AS A MEDIATION VARIABLE
}

\author{
A A Ngurah Bagus Danendra \\ Faculty of Economic and Business Udayana University, Bali, Indonesia \\ bagusdanendra21@gmail.com
}

\section{Agoes Ganesha Rahyuda}

Faculty of Economic and Business Udayana University, Bali, Indonesia

\begin{abstract}
The purpose of this study was to analyze and explain the mediating role of job satisfaction on the workload relationship on employee performance at PT. Amanaid. The research population was PT. Amanaid with a total sample of 40 respondents. The sampling technique is done is a saturated sample technique. The research instrument used questionnaires and analysis methods using Partial Least Square (PLS) with SmartPLS 2.0 software. The results of the study show (1) workload has a negative and significant effect on job satisfaction. (2) Negative and significant workload on employee performance. (3) Job satisfaction has a positive and significant effect on employee performance. (4) Job satisfaction is a mediating variable that has a positive and significant effect on workload and employee performance, meaning that job satisfaction has an important role in mediating workloads on employee performance. The implications of the results of this study indicate that workload is found as a major factor in improving employee performance. If the workload felt by employees is low, it can increase job satisfaction and employee performance. Suggestions on job satisfaction research are proven to mediate partially the relationship between workload on employee performance, so it is recommended to organizations to pay attention to employee workload because it can improve job satisfaction and ultimately improve employee performance. In addition, this study can also expand the research orientation within a larger organization or wider population.
\end{abstract}

Keywords: workload, job satisfaction, employee performance 


\section{Introduction}

The quality of work of employees at waste treatment companies, namely, the accuracy of employees when installing waste processing equipment in order to function properly, the installation of waste treatment equipment is carried out in accordance with established standards. The work quantity of employees in waste processing companies is in making waste processing products for example in one month can make 3 products where only targeted to produce only two, but employees are able to make 3 products. Then the timeliness of waste processing companies is that employees can make waste processing products in a timely manner, besides that when employees install waste processing equipment, employees can finish it on time according to the time specified. If employee performance is good and meets employee performance indicators, it will have a good impact on the company, can increase company profits so that the company is able to compete, the company will always develop and corporate goals can be achieved. It is better if the employee's performance is bad, it can reduce the company's profits, the company's goals cannot be achieved so that the company's performance is reduced and eventually the company can go bankrupt.

Job satisfaction becomes important in a company because employee job satisfaction is closely related to the work results of employees and the survival of the company concerned. Employees will feel comfortable when working gets job satisfaction as expected (Koesmono, 2005). Altaf and Mohamad Atif (2011) found that high workloads had a negative effect on job satisfaction. In Mustapha's research (2013) states that job satisfaction is effect by daily workload, employees are more satisfied when they are given a lower workload. Lower job satisfaction is found in higher workloads in the Mansoor, et. al (2011). So that the lower the workload, the higher job satisfaction will be so that it can improve employee performance. Research conducted by Perera et al. (2014) states that job satisfaction has a positive effect on employee performance. When employees are satisfied, they will work as effectively as possible so that they will improve their performance in the organization.

\section{Literature Review and Hyphotesis Development}

Increasingly tight business competition requires companies to be able to compete with other organizations. In order to compete, companies must pay attention to the performance of their employees. Because if the employee's performance is good then the company's performance is good so that it can increase the profit of the company and the company is growing. Employee performance must always be considered so that the company can run well and in accordance with the company's goals The factors that can affect employee performance are workload. The greater the workload felt by employees, the lower the employee's performance, so the company must always pay attention to the workload of employees. Research by Ali et al. (2013) suggested that there was a positive relationship between employee work hours and employee productivity and there was a negative relationship between workload and employee productivity. Mohamad Atif (2011) found that high workloads had a negative effect on job satisfaction. When the workload of employees is in accordance with the work it can increase job satisfaction so that it can improve employee performance.

\section{The Effect of Workload on Employee Performance}

The research conducted by Shah et. Al. (2011) stated that workload had a negative effect on performance. The higher the workload borne by the employee, the lower the employee's performance. Companies must 
reduce the workload borne by employees, workload must be adjusted to the duties and responsibilities of employees so that employees do not feel burdened so as to improve employee performance. The results of research conducted by Beal et. al (2005) states that workload has a negative effect on employee performance. The results of the same study were also found in Bekker and Demerouti (2007), Barnes and Van Dyne (2009). Based on the empirical evidence, the following hypotheses can be formulated:

H1: Workload has a significant negative effect on employee performance.

\section{The Effect of Workload on Job Satisfaction}

In a study conducted by Rehman et. al. (2012) states that there is a positive relationship between workload and job satisfaction. Employees will feel comfortable if when work gets job satisfaction as expected (Koesmono, 2005). Mustapha and Ghee (2013) provide results, there is a significant negative relationship between workload and job satisfaction. In the study stated that job satisfaction is effect by daily workload, employees are more satisfied when they are given a lower workload. Lower job satisfaction was found in higher workloads in Mansooret's research. al. (2011). In the Tunggareni and Thinni Nurul study (2013) finding nursing staff who have a moderate objective workload tends to have a greater level of job satisfaction than a high objective workload. If the workload given is high or exceeds the capacity capacity of the employee, it will have a negative impact resulting in a decrease in job satisfaction. Based on the empirical evidence, the following hypotheses can be formulated:

H2: Workload has a significant negative effect on job satisfaction

\section{The Effect of Job Satisfaction on Employee Performance}

Research conducted by Kurniawan (2011) has the result that job satisfaction has a positive effect on employee performance. So the more satisfied the employee, the employee will increasingly show his best performance. Conversely, if the employee does not feel satisfied at work, then in him will feel a sense of laziness, so that it will have an impact on decreasing performance. The results of research conducted by Timothy et al (2007) also found that job satisfaction has a significant effect on employee performance. According to Judge et al. (2001), job satisfaction must be maintained to improve organizational performance. Job satisfaction is the emotional attitude of someone who is pleasant and loves his job. Sule et al. (2014) in his study stated that job satisfaction has a positive and significant effect on employee performance. Elarabi and Johari (2014) in their study stated that job satisfaction has a positive and significant effect on performance. Research conducted by Perera et al. (2014) states that job satisfaction has a positive effect on employee performance. When employees are satisfied, they will work as effectively as possible so that they will improve their performance in the organization. The same thing was expressed by Dizgah et al. (2012). Based on the empirical evidence, the following hypotheses can be formulated:

H3: Job satisfaction has a significant positive effect on employee performance.

\section{The Role of Job Satisfaction in Mediating the Effect of Workload on Employee Performance}

Mustapha and Ghee (2013) provide results, there is a significant negative relationship between workload and job satisfaction. In the study stated that job satisfaction is effect by daily workload, employees are more satisfied when they are given a lower workload. According to Judge et al. (2001), job satisfaction must be maintained to improve organizational performance. Job satisfaction is the emotional attitude of someone who is pleasant and loves his job. Sule at el (2014) in his research stated that job satisfaction has a positive 
and significant effect on employee performance. Elarabi and Johari (2014) in their study stated that job satisfaction has a positive and significant effect on performance. Research conducted by Perera et al. (2014) states that job satisfaction has a positive effect on employee performance. The research conducted by Amalia (2017) found that there is a positive and significant indirect effect between workload on performance and job satisfaction. Workload effects work performance and satisfaction. Which means that if the workload given is appropriate then job satisfaction will increase and then produce better performance.

H4: Job satisfaction mediates the effect of workload on employee performance

\section{Methods}

The population used in this study were employees of PT. Amanaid. Number of employees of PT. Amanaid as many as 40 people. The sampling method in this study uses a saturated sample method or census, which is a sampling technique using the entire population as research respondents. Data was collected through interviews and questionnaires followed by data analysis using path analysis techniques to be interpreted and in the final stages conclusions and suggestions were given.

\section{Findings}

Endogenous variables in this study are: employee performance $(\mathrm{Y})$ and job satisfaction $(\mathrm{M})$. The coefficient of determination $\left(R^{2}\right)$ of each endogenous variable can be presented in Table 1 . 
Journal of Business Management and Economic Research (JOBMER), vol.3, issue.8, pp.40-49

Table 1. R-square

\begin{tabular}{lcc}
\hline & Endogenous & R-square \\
\hline Performance $(\mathrm{Y})$ & 0,927 \\
\hline Job Satisfaction $(\mathrm{M})$ & 0,882 \\
\hline
\end{tabular}

Primary Data, 2019

To measure how well the observation value is generated by the model and also its parameter estimation, it is necessary to calculate $\mathrm{Q}^{2}$ as follows:

$$
\begin{aligned}
\mathrm{Q}^{2} & =1-\left(1-\left(\mathrm{R}_{1}\right)^{2}\right)\left(1-\left(\mathrm{R}_{2}\right)^{2}\right) \\
& =1-(1-(0,927)(1-(0,882) \\
& =1-(0,073)(0,118) \\
& =1-0,008 \\
& =0,992
\end{aligned}
$$

The magnitude of $\mathrm{Q}^{2}$ has a value with a range of $0<\mathrm{Q}^{2}<1$, where getting closer to 1 means that the model is getting better. The results of the calculation obtained $\mathrm{Q}^{2}$ value is 0.889 , so it can be concluded that the model has good predictive relevance $\left(\mathrm{Q}^{2}=0.889>0\right)$.

\section{Direct Effect}

This study uses the Partial Least Square (PLS) approach to test and analyze the research hypotheses previously stated. The results of the analysis of the empirical model of research using the Partial Least Square (PLS) analysis tool can be seen in Figure 1 below:

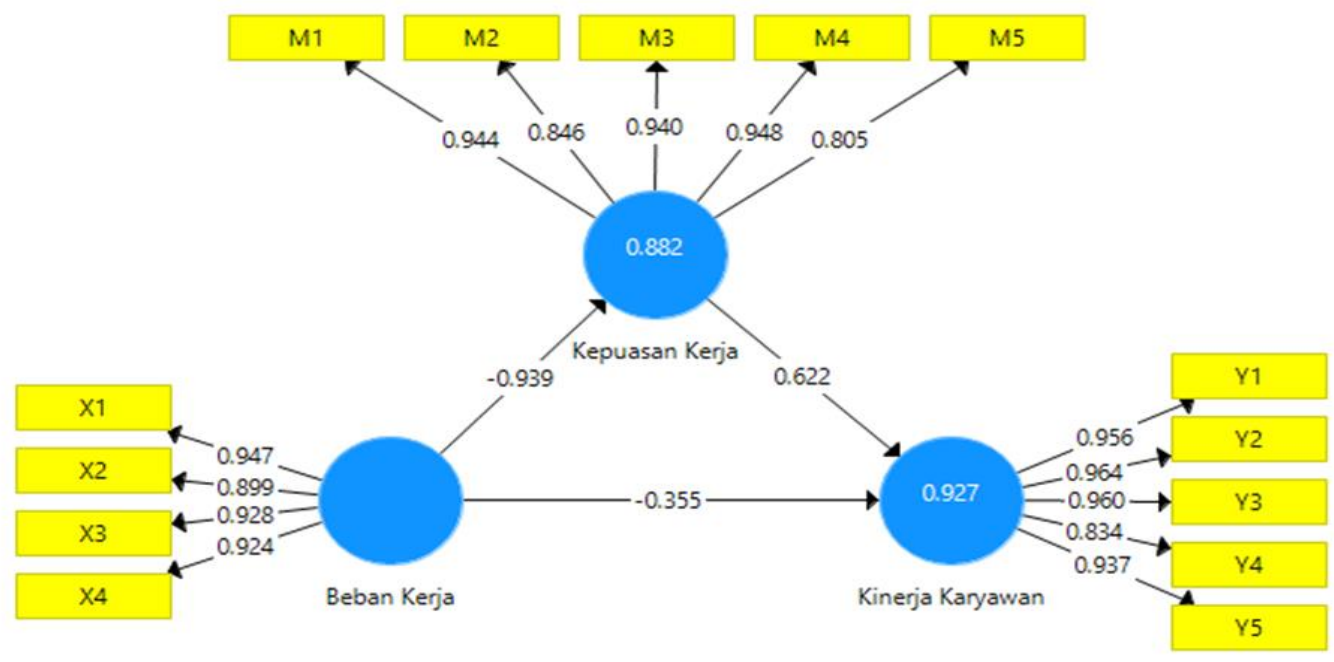

Figure 1. PLS Result

The significance of the estimated parameters provides very useful information about the relationship between the research variables. The basis used in testing the hypothesis is the value found in the output path coefficients presented in Table 2 below. 
Table 2. Path Coefficients

\begin{tabular}{lccc}
\hline \multicolumn{1}{c}{ Construct } & Path Coefficients & t statistics & Description \\
\hline Workload ->Employee Performance & $-0,355$ & 2,447 & Accepted \\
\hline Workload ->Job Satisfaction & $-0,939$ & 45,886 & Accepted \\
\hline Job Satisfaction ->Employee Performance & 0,622 & 4,414 & Accepted \\
\hline
\end{tabular}

Primary Data, 2019

Hypothesis testing is done using $\mathrm{t}$-statistics. If the value of $\mathrm{t}$-statistics $\geq \mathrm{t}$-table value (1.96), then Ho is rejected and the research hypothesis is accepted. In table 2, it can be seen that the workload variable on employee performance has a correlation coefficient of -0.355 and the value of $t$ statistics is 2.447 . This shows if there is a significant negative effect between workload on employee performance. The lower the workload, the higher the employee's performance. In the table it can be seen that the workload has a correlation coefficient value of -0.939 and the value of $t$ statistics is 45,886 . This shows if there is a negative and significant influence between workload on job satisfaction. The lower the workload of an organization, the higher the job satisfaction of an organization. Furthermore the job satisfaction variable has a correlation coefficient of 0.622 and $t$ statistics of 4.414 . This shows if there is a significant positive effect between job satisfaction on employee performance. The higher the job satisfaction, the higher the employee's performance. Based on the data above, it can be concluded that the hypothesis in this study was entirely accepted.

\section{Job Satisfaction Mediating on Workloads to Employee Performance}

The results of testing the direct effect indicate that the coefficient value between workload variables and employee performance is -0.355 with t-statistics value of 2.447 . The addition of job satisfaction variables as mediating variables gives a different influence on the direct relationship of workload to employee performance. Testing the mediating variables of company job satisfaction is done by calculating the value of Variance Accounted For (VAF) which can be seen in Table 2

In Table 2 it can be seen that job satisfaction has a direct influence on employee performance of 0.622 . Workload has a direct influence on employee performance by -0.355 . Workload has a direct influence on job satisfaction by -0.939 . The indirect effect between workload and employee performance is $-0,584$. The total influence between work satisfaction and employee performance is 0.622 , the effect of total workload on employee performance is -0.939 and the total effect between workload and job satisfaction is -0.939 .

Table 3. Direct Effect, Indirect Effect and Total Effect

\begin{tabular}{|c|c|c|}
\hline \multirow[b]{2}{*}{ Variable } & \multicolumn{2}{|c|}{ Direct Effect } \\
\hline & Coefficient & $\begin{array}{c}\text { T Statistik } \\
(\mid \text { O/STDEV } \mid)\end{array}$ \\
\hline Workload ->Employee Performance & 0.622 & 4.414 \\
\hline Workload ->Job Satisfaction & -0.355 & 2.447 \\
\hline Job Satisfaction ->Employee Performance & -0.939 & 45.886 \\
\hline Variable & \multicolumn{2}{|c|}{ Indirect Effect } \\
\hline Workload ->Employee Performance & -0.584 & 4.248 \\
\hline Variabel & \multicolumn{2}{|c|}{ Pengaruh Total } \\
\hline Job Satisfaction ->Employee Performance & 0.622 & 4.414 \\
\hline Workload ->Employee Performance & -0.939 & 52.608 \\
\hline Workload -> Job Satisfaction & -0.939 & 45.886 \\
\hline
\end{tabular}


Journal of Business Management and Economic Research (JOBMER), vol.3, issue.8, pp.40-49

\begin{tabular}{llll}
\hline VAF & $->$ & Indirect Effect/Total Effect $(-0,548 /-0,939)$ & 0,583
\end{tabular}

Primary Data, 2019

From the results of calculations in Table 3 it can be interpreted that the role of job satisfaction as a mediator has a VAF value of $0.583(58.3 \%)$. These results indicate that the job satisfaction variable has a role as mediator between workload variables and employee performance. This shows that the lower the workload felt by employees, the higher the job satisfaction felt by employees so that it will improve the company's performance, the hypothesis that job satisfaction serves as a mediator of the relationship between workload and proven employee performance.

\section{Conclusion}

The results of this study have shown that workload has a negative and significant effect on employee performance, workload has a negative and significant effect on job satisfaction, job satisfaction that has a positive and significant effect on employee performance and job satisfaction as mediating the effect of workload on employee performance.

Based on these findings, it supports the theory that the lower the workload, the higher job satisfaction and employee performance. Job satisfaction also plays a role in mediating workloads on employee performance. The results of this study are expected to be empirical evidence for future research and able to enrich the development of human resource management science related to workload, employee performance and job satisfaction as mediating the effect of workload on employee performance.

The survey results show that workload is an important factor in job satisfaction and the performance of employees of PT. Amanaid. Indicators making decisions in work are important factors in workload variables to improve job satisfaction and improve employee performance. Employees who are given the opportunity to make decisions at work, they feel trusted and unencumbered so they are satisfied with their work. Based on the results of the sincerity survey in work can also improve employee performance. Employees who are serious in doing their work can complete the work according to the target.

The survey results show that indicators of high concern in job satisfaction need to be considered because it can have an impact on employee performance. High concern needs to be considered in order to improve the ability to work together so that cooperation can be established if there is concern among employees. So that it can improve the performance of employees of PT. Amanaid.

\section{References}

Ali, Yassin Sheikh., Abdiaziz Abdi Ali., Abdiqani Ali Adan .2013. Working Conditions And Employees' Productivity In Manufacturing Companies In Sub-Saharan African Context: Case Of Somalia. Educational research international. 2(2), 2307-3721.

Altaf, A., dan Awam, M. 2011. Moderating Affect of Workplace Spirituality on the Relation of the Job Overload and Job Satisfaction. Journal of Business Ethics. 104(1), 93-94.

Amalia, Lia. 2017. Pengaruh Beban Kerja dan Komitmen TerhadapKinerja dan Kepuasan Kerja Perawat Sebagai Variabel Intervening Pada Rumah Sakit Tabrani Rab Pekanbaru. JOM Fekon. 4(2), 3415-3428.

Amir, Mohamad Faisal. 2015. Memahami Evaluasi Kinerja Karyawan: Konsep dan Penelitian Kinerja di Perusahaan. Jakarta: Mitra Wacana Media 
Journal of Business Management and Economic Research (JOBMER), vol.3, issue.8, pp.40-49

Bakker, A. B., \& Demerouti, E. 2007. The job demands-resources model: State of the art. Journal of Managerial Psychology. 22(3), 309-328.

Barnes, C. M., \& Van Dyne, L. 2009. I'm tired : Differential effects of physical and emotional fatigue on workload management strategies. Human Relation. 62(1), 59-92.

Beal, D. J., Weiss, H. M., Barros, E., \& MacDermid, S. M. 2005. An episodic process model of affective influences on performance. Journal of Applied Psychology. 90(6), 1054-1068.

Cole, D., Panchanadeswaran, S., \& Daining, C. 2004. Predictors of job satisfaction of licensed social workers: Perceived efficacy as a mediator of the relationship between workload and job satisfaction. Journal of Social Service Research, 31(1), 1-12.

Dizgah, Morad., Mehrdad Goodarzvand Chegini, dan Roghayeh Bisokhan. 2012. Relationship between Job Satisfaction and Employee Job Performance in Guilan Public Sector. Journal of Basic and Applied Scientific Research. 2 (2), 1735-1741.

Elarabi, Hasan Mohamed dan Johari, Fuadah. 2014. The Determinant Factors Effecting the Job Satisfaction and Performance in Libyan Government Hospital. Asian Social Science, 10(8), pp: 55-64.

Ghozali, I. 2011. Aplikasi Analisis Multivariate dengan Program IBM SPSS 19, Edisi ke-5. Semarang. UNDIP.

Hair, J. F., W. C. Black., B. J. Bopin., and R. E. Anderson. 2010. Multivariate Data Analysis A Global Perspective (Seventh Edition). New Jersey: Pearson Education Inc.

Hamzah Uno, Lamtenggo Nina. 2014. Teori Kinerja dan Pengukurannya. Jakarta : Bumi Aksara.

Hariyono,Widodo., Dyah Suryani., Yanuk Wulandari. 2009. Hubungan antara Beban Kerja, Stres Kerja dan Tingkat Konflik dengan Kelemahan Kerja Perawat di Rumah Sakit Islam Yogyakarta PDHI Kota Yogyakarta. Jurnal Fakultas Kesehatan Masyarakat, Universitas Ahmad Dahlan.3(3), 162-232.

Ilyas, Y. 2000. Perencanaan SDM dan Rumah Sakit Teori, Metoda dan Formula. Pusat Kajian Ekonomi Kesehatan FKM UI, Depok. Jakarta: PT Bumi Aksara

Indriantoro, N. dan B. Supomo. 2012. Metodologi Penelitian Bisnis untuk Akuntansi dan Manajemen, Edisi Pertama. Yogyakarta BPFE.

Jaya, I., and Sumertajaya, I. 2008. Pemodelan Persamaan Struktural Dengan Partial Least Square. Semnas Matematika dan Pendidikan Matematika. 1(1), 118-132.

Judge, T. A., Thoresen, C.J., Bono, J.E. dan Patton, G. K. 2001. The Job Satisfaction-Job Performance Relationship: A Qulitative and Quantitative Review. Psychological Bulletin. 127(3), 376-407.

Keban, Yeremias T .2004. Enam Dimensi Strategis Administrasi Publik Konsep, Teori dan Isu. Gava Media : Yogyakarta.

Koesmono, Teman. 2005. Pengaruh Budaya Organisasi Terhadap Motivasidan Kepuasan Kerja Serta Kinerja Karyawan Pada Sub Sektor Industri Pengolahan Kayu Skala Menengah Di Jawa Timur. Jurnal Managemen dan Kewirausahaan, 7(2), 171-188.

Kreitner, Robert dan Angelo Kinicki.2014. Perilaku Organisasi. Jakarta: Salemba Empat.

Luthans, Fred. 2006. Organizational Behavior : An Evidence-Based Approach. New York: McGraw-Hill. 
Mansoor, Muhammad., Sabtain Fida. 2011. The Impact of Job Stres on Employee Job Satisfaction A study on Telecommunication Sector of Pakistan. Journal of Business Studies Quarterly. 2(3), 50-56.

Mathis, R.L dan Jackson. 2011. Human Resource Management. Jakarta : Salemba Empat.

Maulizar. S. M dan M. Yunus. 2012. Pengaruh kepemimpinan transaksional dan transformasional terhadap kinerja karyawan bank Syariah Mandiri cabang Banda. Jurnal Manajemen. 1(1),58-65.

Munandar. 2011. Manajemen Mutu, Bogor: PT Gramedia.

Mustapha, Noraani dan Ghee, W. Y. 2013. Examiningi Faculty Workloadias Antencedent of Job Satisfaction among Academic Staff of Higher Public Education on Kelantan, Malaysia. Journal Business and Management Horizons. 1(1), 10-16.

Nurmianto, Eko. 2003. Ergonomi Konsep Dasar dan Aplikasinya. Surabaya: Guna Widya.

Perrera, Gamage Dinoka Nimali, Ali Khatibi, Nimal Navaratna dan, Karuthan Chinna. 2014. “Job Satisfaction And Job Performance Among Factory Employees In Apparel Sector “. Asian Journal of Management Science E Educatio., 3(1), 96-104.

Rehman, Muttieur, RabbiaIrum, NamraTahir, Zara Ijaz, Uzma Noor, Ume Salma,. 2012. The Impact of Job Stress on Employee Job Satisfaction: An study on Private Colleges of Pakistan. Journal of Business Studies Quarterly.3(3), 50-56.

Ristiana, Merry. 2013. Pengaruh Komitmen Organisasi dan Kepuasan Kerja Terhadap Organizational Citizenship Behavior (OCB) dan Kinerja Karyawan Rumah Sakit Bhayangkara Trijata Denpasar. Jurnal Ilmu Ekonomi \& Manajemen. 9(1),56 - 70 .

Rivai, Veithzal. 2009. Manajemen Sumber Daya Manusia Untuk Perusahaan: Dari Teori Ke Praktik. Jakarta: PT Raja Grafindo Persada.

Rivai, Vethzal \& Basri. 2005. Peformance Appraisal: Sistem yang tepat untuk Menilai Kinerja Karyawan dan Meningkatkan Daya Saing Perusahan. Jakarta: PT. Raja Grafindo Persada.

Robbins, Stephen P. dan Judge, T.A. 2007. Perilaku Organisasi. Penerbit Salemba Empat : Jakarta.

Shah SSH, Jaffari AR, Aziz J, Ejaz W, UI-Haq I, Raza SN .2011. Workload and performance of employees. Interdisciplinary Journal of Contemporary Research in Business. 3(5), 256-267.

Solihin, M., D. Ratmono. 2013. Analisis SEM-PLS dengan WarpPLS 3.0 untuk Hubungan Nonlinier dalam Penelitian Sosial dan Bisnis. Penerbit ANDI, Yogyakarta.

Sugiyono. 2013. Metode Penelitian Bisnis, Cetakan ke-15. Bandung: Alfabeta.

Sule, Ja'afaru Garba, Akeem Tunde Nafiu, dan E. Victor Okpanachi. 2014. An Empirical Study of the Dialectical Relationship between Job Satisfaction and Job Performance of Restaurant Employees in Dekina Local Government of Kogi State, Nigeria. International Journal of Academic Research and Social Sciences, 4(5),596-607.

Suparyadi, H. 2015. Manajemen Sumber Daya Manusia Menciptakan Keungulan Bersaing Berbasis Kompetensi SDM. Yogyakarta: Penerbit ANDI.

Suwatno dan Priasna, D. 2011. Manajemen SDM dalam organisasi publik dan Bisnis. Bandung : Alfabeta. 
Journal of Business Management and Economic Research (JOBMER), vol.3, issue.8, pp.40-49

Tunggareni, Heln Susianti dan Thinni Nurul Rochmah. 2013. Job Satisfaction and Performance of Nurse based on Workload in Bhayangkara Hospital Lumajang. Jurnal Administrasi Kesahatan Indonesia. 1(3), 225-233.

Wiyono, G. 2011. Merancang Penelitian Bisnis dengan Alat Analisis SPSS 17.0 dan Smart PLS 2.0. Yogyakarta: STIM YKPN.

Yuliastuti, R., dan Handaru B.C. 2017. Efektifitas Pengolahan Limbah Cair Industri Abses Menggunakan Flokulan dan Adsorben. Jurnal Teknologi Proses dan Inovasi Industri. 2(2),77-83.

Yusuf, Husmiati. 2011. Pengaruh Kondisi Organisasi terhadap Kejenuhan Kerja Pekerja Sosial yang Bekerja di Panti Sosial Penyandang Cacat di Indonesia. Jurnal Informasi. 16(3), 177-183. 